\title{
Androgen Signaling in Prostate Cancer
}

\author{
Charles Dai, ${ }^{1,2}$ Hannelore Heemers, ${ }^{1,2,3,4}$ and Nima Sharifi ${ }^{1,2,3,4}$ \\ ${ }^{1}$ Cleveland Clinic Lerner College of Medicine, Cleveland, Ohio 44195 \\ ${ }^{2}$ Department of Cancer Biology, Lerner Research Institute, Cleveland Clinic, Cleveland, Ohio 44195 \\ ${ }^{3}$ Hematology \& Medical Oncology, Taussig Cancer Institute, Cleveland Clinic, Cleveland, Ohio 44195 \\ ${ }^{4}$ Glickman Urological \& Kidney Institute, Cleveland Clinic, Cleveland, Ohio 44195 \\ Correspondence: sharifn@ccf.org
}

The androgen-signaling axis plays a pivotal role in the pathogenesis of prostate cancer. Since the landmark discovery by Huggins and Hodges, gonadal depletion of androgens has remained a mainstay of therapy for advanced disease. However, progression to castration-resistant prostate cancer (CRPC) typically follows and is largely the result of restored androgen signaling. Efforts to understand the mechanisms behind CRPC have revealed new insights into dysregulated androgen signaling and intratumoral androgen synthesis, which has ultimately led to the development of several novel androgen receptor (AR)-directed therapies for CRPC. However, emergence of resistance to these newer agents has also galvanized new directions in investigations of prereceptor and postreceptor AR regulation. Here, we review our current understanding of AR signaling as it pertains to the biology and natural history of prostate cancer.

t has now been more than 70 years since Huggins and Hodges (1941) first exposed the central role of androgen signaling in prostate cancer by showing that orchiectomy induces considerable tumor regression. Their seminal discovery was recognized with the Nobel Prize in Medicine in 1966 and, to this day, gonadal testosterone depletion remains a mainstay of therapy for advanced disease (Mohler et al. 2012). It is now evident that the majority of prostate cancers express the androgen receptor (AR) throughout the course of the disease (Sadi et al. 1991; Ruizeveld de Winter et al. 1994; Attard et al. 2009), and, in recent years, deeper interrogation into the molecular basis of androgen signaling has offered a better understanding of how AR spe- cifically directs cancer cell behavior. Taken together, these findings have solidified the importance of androgen signaling in prostate cancer pathogenesis.

Nevertheless, androgen-deprivation therapy (ADT) by chemical or surgical castration is invariably followed by the recurrence of castration-resistant prostate cancer (CRPC) within a median of 14-20 months (Sharifi et al. 2005). Once thought to be an androgen-independent state, it is now recognized that this is generally not the case (Mohler 2008). Progression to CRPC is typically heralded by a rising prostate-specific antigen (PSA) despite castrate concentrations of testosterone, suggesting that inappropriate restoration of the AR signaling

Editors: Michael M. Shen and Mark A. Rubin

Additional Perspectives on Prostate Cancer available at www.perspectivesinmedicine.org

Copyright (C) 2017 Cold Spring Harbor Laboratory Press; all rights reserved; doi: 10.1101/cshperspect.a030452

Cite this article as Cold Spring Harb Perspect Med 2017;7:a030452 
C. Dai et al.

axis remains pivotal to this progressive and lethal form of disease (Scher and Sawyers 2005; Ryan and Tindall 2011). Efforts to identify the mechanisms underlying CRPC have revealed new insights into dysregulated androgen signaling, including how AR may incur gain-of-function through mutations, splice variants, and aberrant coregulation (postreceptor regulation), as well as how intracrine steroidogenesis (prereceptor regulation) critically contributes to tumor progression. This has ultimately led to the development of several novel AR-directed therapies, which have since clinically validated many of these concepts (Sharifi 2010; Chang and Sharifi 2012). In this work, we review our current understanding of the androgen signaling axis as it directly pertains to the biology of prostate cancer in its various stages, highlighting aspects of prereceptor and postreceptor regulation (Ryan and Tindall 2011; Heemers 2014), as well as emerging AR-directed therapeutic strategies and ongoing areas of research.

\section{ANDROGEN BIOSYNTHESIS IN NORMAL MALE PHYSIOLOGY}

Androgens play an essential role in the development and maintenance of normal male physiology (Griffin 1992). The biosynthesis of all steroid hormones begins with 27-carbon cholesterol, which undergoes stepwise modification by a small complement of enzymes first to 21 carbon steroids (progestins) and subsequently to 19-carbon androgens (Fig. 1). In normal male physiology, early steps in steroidogenesis occur efficiently in two tissues-the adrenal cortex and the testes-so that these tissues together play a major role in the synthesis of circulating steroids (Sharifi and Auchus 2012). Further downstream reactions in the steroidogenic pathways are then refined by specific isoenzymes in target tissues to meet site-specific requirements.

The testes are responsible for the biosynthesis of the majority of testosterone in circulation, with comparatively minor input from the

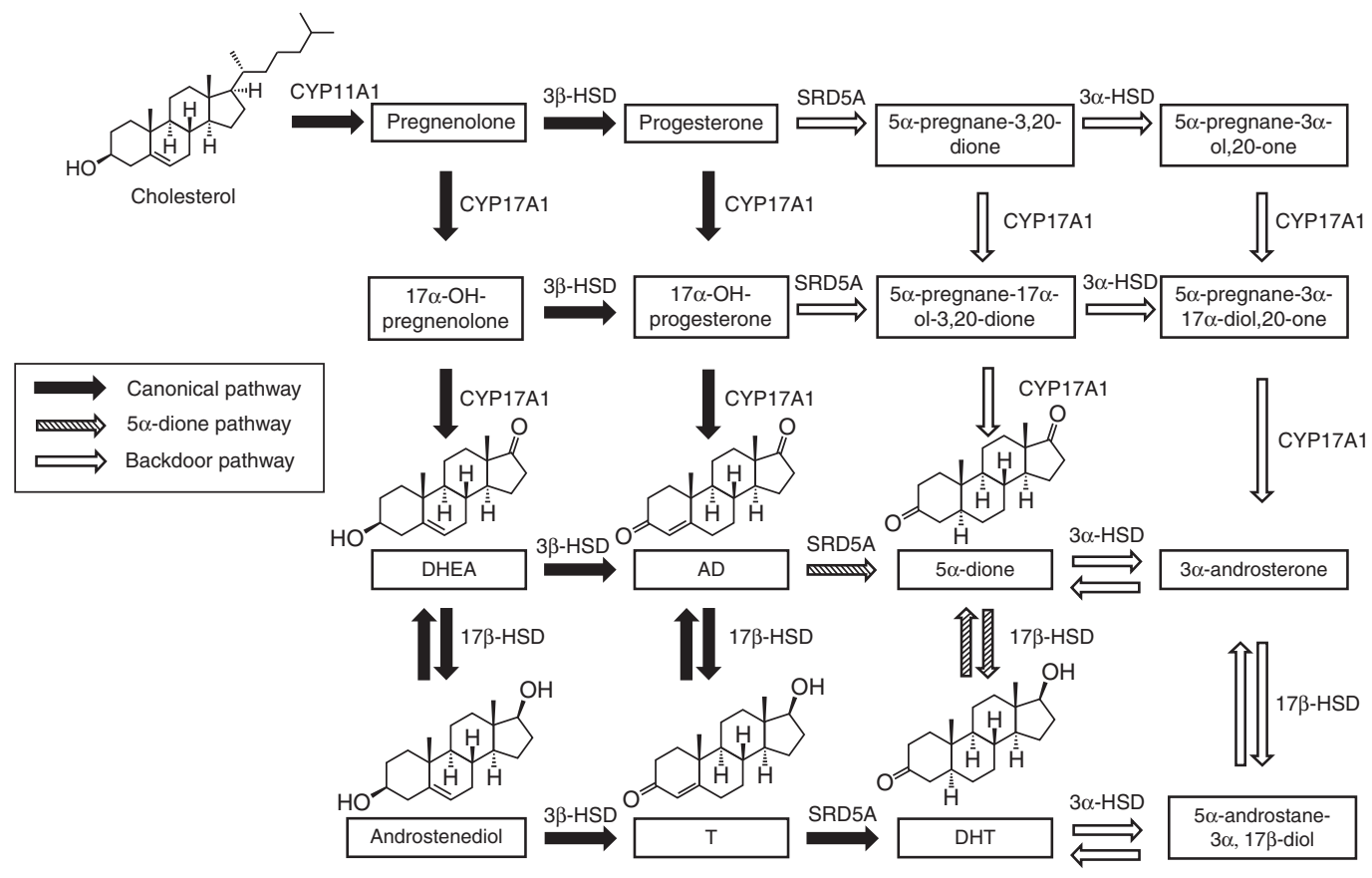

Figure 1. Pathways of androgen biosynthesis in normal physiology and prostate cancer. Key enzymes are denoted next to arrows for each reaction. Specific isoenzymes responsible for particular reactions are discussed in the main text. DHEA, dehydroepiandrosterone; $\mathrm{AD}$, androstenedione; T, testosterone; DHT, dihydrotestosterone. 
adrenal glands (Nakamura et al. 2009). In both the zona reticularis of the adrenal cortex and Leydig cells of the testes, steroidogenesis starts with the side-chain cleavage of cholesterol by CYP11A1 (cholesterol side-chain cleavage enzyme, P450scc) to generate pregnenolone. Pregnenolone is then converted by CYP17A1 (17hydroxylase/17,20-lyase, $\mathrm{P} 450 \mathrm{c} 17$ ) to $17-\mathrm{OH}$ pregnenolone and subsequently to dehydroepiandrosterone (DHEA). Although much of the nascent DHEA in the adrenal cortex is readily sulfonated by sulfotransferase (SULT2A1) for eventual secretion into circulation, testicular Leydig cells lack SULT2A1 and abundantly express $3 \beta$-hydroxysteroid dehydrogenase 2 (3 $\beta$ HSD2), which enables further downstream metabolism of DHEA to testosterone (Sharifi and Auchus 2012). Two final steps are required for the generation of testosterone in the testes, primarily mediated by $3 \beta-H S D 2$ and $17 \beta$-hydroxysteroid dehydrogenase 3 (17 $\beta$-HSD3). A requirement for the latter enzyme is shown by loss-of-function mutations that lead to pseudohermaphroditism (Geissler et al. 1994). Following synthesis, testosterone is secreted into serum, in which it is mostly bound to sex hormone-binding globulin (SHBG) and albumin (Dunn et al. 1981; Rosner et al. 1991). The degree of bound and unbound testosterone probably exists at equilibrium, with free testosterone thought to readily undergo cellular uptake through passive diffusion into peripheral tissues (Dunn et al. 1981). Intriguingly, some studies have shown that exogenous administration of testosterone and dihydrotestosterone (DHT) leads to increased levels of serum but not necessarily intraprostatic androgens (Page et al. 2011; Thirumalai et al. 2016), indicating that currently underappreciated mechanisms may be at play to tightly regulate intracellular androgens within a narrow concentration range.

In prostate cells, testosterone may act directly on AR or be irreversibly converted to DHT by $5 \alpha$-reductase, of which there are two isoenzymes (SRD5A1, SRD5A2) (Russell and Wilson 1994; Zhu and Imperato-McGinley 2009). In particular, SRD5A2 is the predominant enzyme present in benign prostatic tissue that me- diates the testosterone $\rightarrow$ DHT reaction and is necessary for proper development of the male phenotype (Wilson 2001). A loss-of-function mutation in SRD5A2 causes $5 \alpha$-reductase deficiency, manifesting in pseudohermaphroditism and failure to develop a normal prostate (Imperato-McGinley et al. 1974; Andersson et al. 1991). The requirement for DHT in prostatic growth has also been confirmed through the development of $5 \alpha$-reductase inhibitors as an effective treatment for benign prostatic hyperplasia (BPH) (Rittmaster 1997; Steers 2001; Marks 2004). Recognizing the potential complement of enzymes that can participate in androgen biosynthesis is essential, because prostate cancers may frequently commandeer this enzymatic machinery to sustain steroidogenesis and fuel tumor growth, particularly following ADT (Stanbrough et al. 2006; Montgomery et al. 2008; Knudsen 2014).

\section{PRERECEPTOR MODULATION OF AR SIGNALING}

Androgen synthesis is tightly governed by the hypothalamic-pituitary-gonadal axis. Pulsatile release of hypothalamic gonadotropinreleasing hormone $(\mathrm{GnRH})$ stimulates luteinizing hormone (LH) secretion from the anterior pituitary gland, which signals for the production of testosterone in the testes. Testosterone subsequently exerts negative feedback on the hypothalamus and pituitary gland. The pulsatile nature of GnRH is necessary to sustain continued LH secretion; persistent GnRH stimulation leads to ensuing desensitization, which is the rationale behind administering long-acting $\mathrm{GnRH}$ agonists for ADT. Following an initial flare, serum testosterone concentrations are effectively suppressed by GnRH agonists to medically castrate levels of $<50 \mathrm{ng} / \mathrm{dL}$ (Nishiyama 2014).

Although testosterone is a physiologic AR ligand sharing a similarly high equilibrium affinity as DHT (Wilson and French 1976), DHT is the principal androgen found within the prostatic cell nucleus (Bruchovsky and Wilson 1968) and is approximately 10 -fold more potent 


\section{Dai et al.}

in the stimulation of AR target genes (Deslypere et al. 1992). This difference is thought to be attributed to the greater hydrophobicity of DHT, which stabilizes the ligand-receptor state through intermolecular interactions and decreases the ligand dissociation rate (Zhou et al. 1995; Askew et al. 2007). Therefore, the principal effect achieved through testosterone depletion is likely attributed to the intraprostatic reduction in DHT. However, despite castrate concentrations of testosterone and an observed tumor response in $80 \%-90 \%$ of patients, incomplete depletion of prostate cancer tissue androgens occurs following ADT. Residual concentrations of intratumoral DHT can remain at $10 \%-40 \%$ of pretreatment levels (Forti et al. 1989; Labrie et al. 1993; Page et al. 2006), even before the development of CRPC (Nishiyama et al. 2004). This is substantial because this concentration range of typically $1 \mathrm{nM}$ remains sufficient to permit AR signaling, AR target gene expression, and tumor growth both in vitro and in vivo (Gregory et al. 1998, 2001; Mohler et al. 2004; Mostaghel et al. 2007). Multiple studies have now corroborated the presence of residual androgens in recurrent tumors after castration (Geller et al. 1978; Titus et al. 2005; Montgomery et al. 2008), together signifying that the persistence of AR signaling likely promotes the emergence of CRPC. This is perhaps unsurprising, given that the onset of CRPC is predictably and near universally accompanied by an increase in PSA, a widely used clinical biomarker expressed by an AR-responsive gene (Ryan et al. 2006). Furthermore, recent therapeutic advances in the Food and Drug Administration (FDA) approval of novel, life-prolonging AR-directed therapies, such as the potent second-generation competitive AR antagonist enzalutamide (Scher et al. 2012; Beer et al. 2014) and the androgen synthesis inhibitor abiraterone acetate (de Bono et al. 2011; Ryan et al. 2015), have provided the highest level of clinical evidence for this evolving paradigm. A number of similar agents are currently under clinical investigation, which could soon add to a growing arsenal of therapeutic options for men with metastatic CRPC (Dellis and Papatsoris 2016).

\section{INTRACRINE ANDROGEN BIOSYNTHESIS IN PROSTATE CANCER}

A variety of mechanisms may explain the restoration of competent AR signaling in CRPC. These include AR overexpression and amplification, intracrine androgen synthesis, acquisition of constitutively active AR splice variants, and gain-of-function mutations, deregulated AR coactivators/corepressors that sensitize AR in response to ligand binding, and ligand-independent signaling and redundant downstream cross talk (Sharifi 2013; Ferraldeschi et al. 2015). Of note, these postulated mechanisms are not necessarily mutually exclusive and may arise together under the selective pressure of ADT. Importantly, the persistence of physiologically significant intratumoral androgens despite castration indicates that prereceptor regulation remains central to many of these mechanisms to further fuel tumor growth (Zhang et al. 2016). To support this are observations that castrate tumors often up-regulate key steroidogenic enzymes to utilize alternative sources of androgen synthesis (Holzbeierlein et al. 2004; Stanbrough et al. 2006; Montgomery et al. 2008).

Several possibilities exist for the origin of these intratumoral androgens. The first is the de novo pathway, which begins with cholesterol and requires multiple steps in the synthesis of DHT. This may occur either via the canonical route as described in normal physiology (Sharifi and Auchus 2012), or alternatively via a "backdoor" pathway, which involves intratumoral CYP17A1 activity to convert pregnanes to androgens that are then $5 \alpha$ - and 3-keto-reduced, with eventual terminal conversion to DHT (Fig. 1) (Fiandalo et al. 2014). Whether tumors express the complete repertoire of steroidogenic enzymes required to generate androgens from cholesterol remains to be fully elucidated (Hofland et al. 2010). On the other hand, circulating adrenal androgens, which are abundant in the form of DHEA and a larger depot of sulfated DHEA-S, are readily interconverted to DHT via an abbreviated series of steps (Mostaghel 2013). DHT concentrations in prostatic tissues of castrate men positively correlate with serum DHEA/DHEA-S levels (Page et al. 2006) and 
treatment with abiraterone acetate markedly reduces serum DHEA concentrations (Attard et al. 2012; Taplin et al. 2014; Mostaghel 2014a), while aptly suppressing intraprostatic androgen levels (Mostaghel et al. 2014). To generate downstream testosterone and DHT, DHEA must first undergo oxidation of its $3 \beta$ hydroxyl group and $\Delta^{5}$ to $\Delta^{4}$ isomerization to form androstenedione (AD). This rate-limiting step is catalyzed by $3 \beta-\mathrm{HSD}$, for which there are two human isoenzymes: $3 \beta-H S D 1$ and $3 \beta$-HSD2. In peripheral tissues, including the prostate, $3 \beta-\mathrm{HSD} 1$ predominates, whereas $3 \beta$ HSD2 is expressed preferentially in the adrenal glands and gonads (Simard et al. 2005). Given its unique position within the steroidogenic pathway, $3 \beta-H S D 1$ is likely a critical enzymatic gatekeeper that confers on tumors the ability to harness adrenal androgens (Evaul et al. 2010). In fact, a gain-of-function missense in $3 \beta$ HSD1 has recently been described, which remarkably augments the capacity of this enzyme to drive conversion of DHEA $\rightarrow \mathrm{AD}$, thereby permitting more efficient DHT synthesis (Chang et al. 2013). This missense arises from a single nucleotide polymorphism (SNP) at position $1245(\mathrm{~A} \rightarrow \mathrm{C})$, substituting an asparagine for threonine at amino acid position 367. The functional consequence of this alteration, which can occur as either a somatic mutation or germline variant, is an enzyme protein product that is rendered resistant to ubiquitinmediated degradation, resulting in intracellular accumulation. Notably, it appears that ADT may select for this particular mutation; CRPC tumors from patients who are germline heterozygous variants will not infrequently show loss of heterozygosity or acquire a second variant allele by way of a somatic mutation (Chang et al. 2013). This leads to markedly stable enzyme expression, detailing yet another adaptive mechanism through which tumors may subvert androgen deprivation. Furthermore, inheritance of the gain-of-function HSD3B1(1245C) SNP is associated with rapid resistance and poorer survival after ADT in patients with prostate cancer (Hearn et al. 2016).

The subsequent conversion from $\mathrm{AD}$ to DHT requires two additional reactions. In the canonical pathway, $\mathrm{AD}$ first forms testosterone through reduction of its 17 -keto moiety mediated by $17 \beta$-HSD, before $5 \alpha$-reduction to DHT by SRD5A (Fig. 1). In contrast, an alternative pathway has been described, in which $\mathrm{AD}$ can bypass testosterone as an obligate precursor, instead undergoing $5 \alpha$-reduction to an intermediate $5 \alpha$-androstanedione ( $5 \alpha$-dione), followed by 17-keto reduction to DHT (Chang et al. 2011). In fact, this " $5 \alpha$-dione pathway" appears to be the favored directionality of adrenal androgen flux in virtually all prostate cancer cell lines as well as in sampled metastatic CRPC biopsies from patients (Chang et al. 2011). Furthermore, in contrast to the robust flux of $\mathrm{AD} \rightarrow 5 \alpha$-dione, the comparable reaction of testosterone $\rightarrow$ DHT is relatively inefficient. This paradoxical shift in the preferred precursor for $5 \alpha$-reduction from testosterone to $\mathrm{AD}$ in CRPC tissues may be explained by the differential expression of $5 \alpha$-reductase isoenzymes in tumors. Expression studies have repeatedly revealed that the transition from benign tissue to high-grade prostate cancers and CRPC is associated with stepwise up-regulation of SRD5A1 and subtotal loss SRD5A2 (Thomas et al. 2008). Given that the optimal substrate for SRD5A1 is $\mathrm{AD}$ rather than testosterone (Thigpen et al. 1993), this genotypic switch may specifically herald an acquired ability of tumors to efficiently harness adrenal androgens to circumvent testosterone depletion. Genetic silencing of SRD5A1 in cell lines effectively abolishes the conversion of adrenal androgens to DHT (Chang et al. 2011).

Because $3 \beta-H S D 1,17 \beta-H S D$, and SRD5A are all required for the generation of DHT from adrenal androgens, pharmacologic inhibition of these enzyme targets has been an active area of clinical interest. Two $5 \alpha$-reductase inhibitors are currently available: finasteride, primarily an SRD5A2 inhibitor, and dutasteride, a dual SRD5A1/SRD5A2 inhibitor (Schmidt and Tindall 2011). These agents have been tested in a variety of settings, including in the prevention of prostate cancer (Azzouni and Mohler 2012; Fleshner et al. 2012; Schröder et al. 2013) and as an adjuvant therapy to additionally suppress residual androgens following ADT (Xu et al. 
C. Dai et al.

2006; Shah et al. 2009). One challenge to SRD5A inhibition is a concomitant rise in upstream testosterone following blockade, which may rescue AR activity and obscure potential therapeutic efficacy (Rittmaster et al. 2008; Chang et al. 2011).

Inhibition of the $17 \beta$-HSD family enzymes instead may potentially overcome this issue. 17 $\beta$-HSD5 (aldo-keto reductase 1C3 [AKR1C3]) is one particular member of this family, which shows a reductive preference for the conversion of $\mathrm{AD} \rightarrow$ testosterone and is broadly implicated in prostate cancer (Adeniji et al. 2013). Expression levels of AKR1C3 are associated with the highest increase in CRPC relative to primary cancer among profiled steroidogenic enzymes; in one study, 58\% of CRPC samples were positively stained for AKR1C3 compared with only $5.6 \%$ of primary cancers (Stanbrough et al. 2006). The design of effective AKR1C3 inhibitors is an ongoing area of investigation. Importantly, inhibitors must show enzyme specificity given multiple closely related aldo-keto reductase isoforms, some of which drive other reactions (Byrns et al. 2011; Adeniji et al. 2013).

Further upstream inhibition of $3 \beta-\mathrm{HSD}$ isoenzymes presents as another potentially viable opportunity for additional androgen suppression. In preclinical models, treatment with abiraterone acetate notably reduces activity of not only CYP17A1 but also $3 \beta-\mathrm{HSD}$ (Evaul et al. 2010). Interestingly, the $\Delta^{5}, 3 \beta$-hydroxyl steroidal structure of abiraterone is amenable to direct enzymatic conversion by $3 \beta-$ HSD to a $\Delta^{4}$, 3-keto congener (D4A), which is an active inhibitor of multiple steroidogenic enzymes, including 3 $\beta$-HSD, CYP17A1, and SRD5A ( $\mathrm{Li}$ et al. 2015). Furthermore, D4A antagonizes AR at levels comparable to enzalutamide ( $\mathrm{Li}$ et al. 2015). A subsequent metabolite of D4A also shows AR agonist activity; the contributory effect of these derivative compounds therefore suggests that pharmacologic blockade of particular metabolic pathways could be a feasible method to limit the production of AR-promoting metabolites, thereby refining the antitumor properties of abiraterone (Li et al. 2016). Given the appreciable role of residual androgen production in driving progression to CRPC, identifying opportunities for intensive and directed suppression of intracrine androgen synthesis remain paramount.

\section{ANDROGEN RECEPTOR STRUCTURE/ FUNCTION}

The AR is a ligand-dependent nuclear transcription factor (TF) and member of the steroid hormone receptor superfamily (Nuclear Receptors Nomenclature Committee 1999). The gene for AR is located on the X chromosome (q1112) and expresses a $110-\mathrm{kDa}$ protein that is 919 amino acids in length, encoded by eight exons (Chang et al. 1988; Lubahn et al. 1989; Tilley et al. 1989). Common in resemblance to other nuclear hormone receptors, the structure of AR is comprised of four separate functionally distinct domains: an amino-terminal domain (NTD), a carboxy-terminal ligand-binding domain (LBD), a DNA-binding domain (DBD), and a flexible hinge region, which joins the LBD and the DBD (Fig. 2) (Gelmann 2002; Claessens et al. 2008).

The main native agonists for AR under normal physiologic conditions are testosterone and DHT. When unoccupied by ligand, AR resides primarily in the cytoplasm, anchored to cytoskeletal elements, and associated in a complex with heat shock proteins (HSP-90, HSP-70, HSP-56) and other chaperone proteins to protect the receptor against degradation (Smith and Toft 2008). Binding of ligand to the cognate receptor causes dissociation from this complex and initiates a sequence of molecular events that eventually leads to AR nuclear translocation and activation of AR target genes (Fig. 3). The LBD is vital to directing this response; this is well illustrated by the fact that a deletion of the LBD renders AR completely unresponsive to androgens (Jenster et al. 1991). Furthermore, the LBD is the target for the most competitive AR antagonists, including enzalutamide (Knudsen and Scher 2009), and is the most frequent site of gain-of-function point mutations (Buchanan et al. 2001). Although AR mutations are relatively infrequent in early-stage hormone-naïve prostate cancers, they are detected in approximately $10 \%-30 \%$ of patients previously treated 


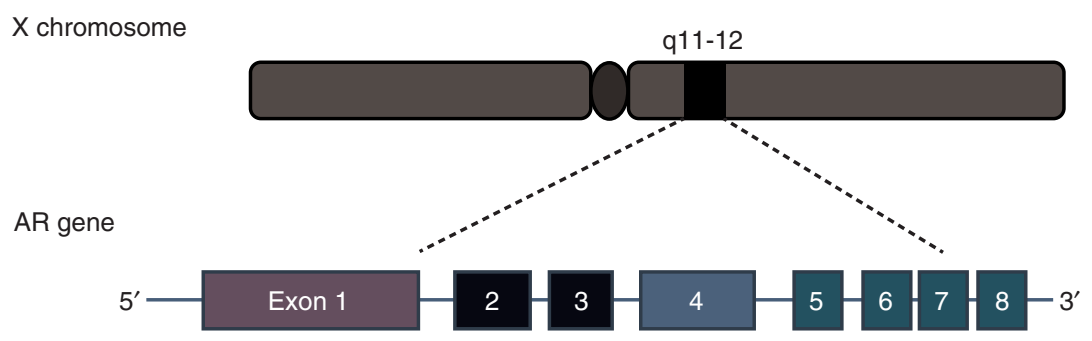

AR protein (full-length)

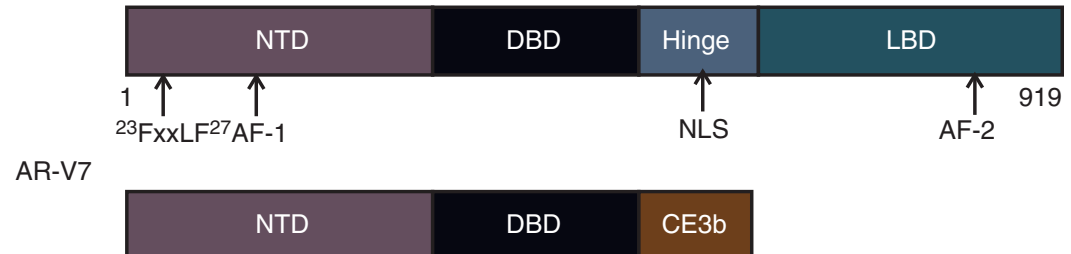

Figure 2. The androgen receptor (AR) gene locus and structure of the AR (full-length and AR-V7). The transcript for wild-type AR full-length (FL) includes eight exons, which correspond to the four respective domains of the AR protein (as depicted by color scheme). AR-V7 includes a cryptic exon region (CE3b) at the carboxyl terminus. NTD, Amino-terminal domain; DBD, DNA-binding domain; LBD, ligand-binding domain; NLS, nuclear localization signal.

with first-generation competitive AR antagonists (Taplin et al. 1995, 2003; Wallén et al. 1999). Acquisition of AR mutations can enhance receptor promiscuity, broadening the range of potential endogenous steroid ligands (Culig et al. 1993; Mostaghel 2014b) or imparting the reversal of AR antagonists to agonists (Veldscholte et al. 1992; Culig et al. 1999; Taplin et al. 1999). The latter is the presumed mechanism by which tumors may regress following the withdrawal of AR antagonist therapy (Scher and Kelly 1993; Hara et al. 2003). Furthermore, this mechanism may explain why tumors refractory to select AR antagonists can show continued susceptibility to alternative agents (Tran et al. 2009; Balbas et al. 2013).

Ligand binding causes a critical conformational change in AR, which not only facilitates the nuclear targeting of AR but also exposes transcriptional activation function 2 (AF-2), a functionally significant hydrophobic binding surface-spanning helices 3, 4, and 12 within the LBD. Through recognition of FxxLF motifs embedded in the NTD (He et al. 2000), AF-2 mediates protein-protein interactions between the carboxyl and amino termini that are necessary for receptor homodimerization, stabilization of the ligand within the ligand-binding pocket, and optimization of AR activity (Doesburg et al. 1997; Berrevoets et al. 1998). AF-2 also enables the recruitment of specific AR cofactors, which bear FxxLF and LxxLL motifs to modulate receptor function (Heery et al. 1997; He et al. 2002). Nuclear translocation is mediated by a bipartite nuclear localization signal (NLS) located within the hinge region, which interacts with cytoskeletal proteins (Ozanne et al. 2000; Thadani-Mulero et al. 2012) to orchestrate the transport of AR via importin- $\alpha$ across the nuclear membrane (Kaku et al. 2008; Ni et al. 2013). Once in the nucleus, AR generally persists in a homodimer localizing to specific recognition sequences designated as androgen response elements (AREs) found within the promoter and enhancer regions of AR target genes (Claessens et al. 2001). Following localization, coregulators, general TFs, and RNA polymerase II are successively recruited to AR to direct the organization of the preinitiation transcriptional complex (Heemers and Tindall 2009). 
C. Dai et al.

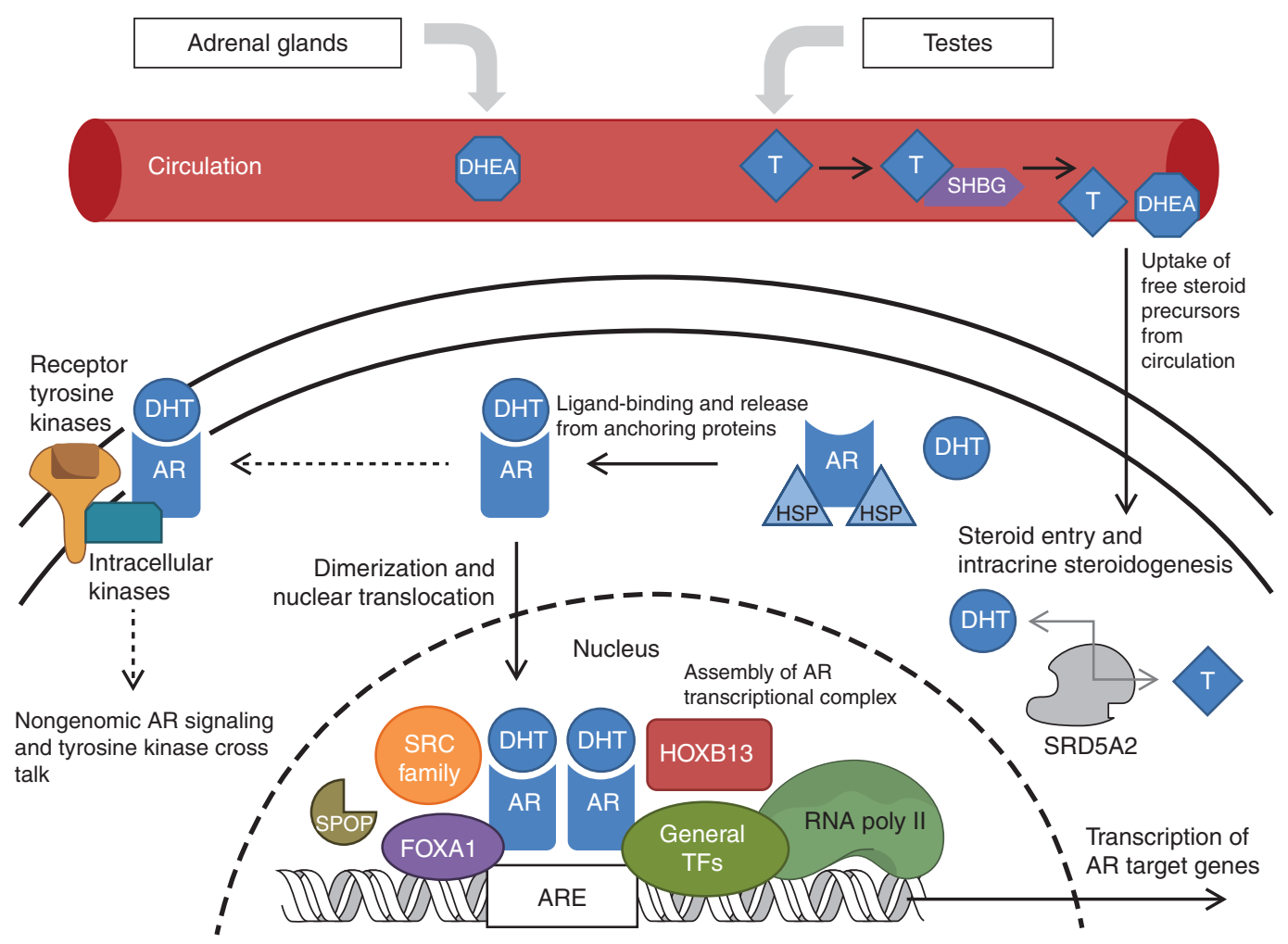

Figure 3. Prereceptor and receptor-level modulation of androgen receptor (AR) action within the prostate cancer cell. Examples of transcriptional coregulators discussed within the text are depicted but are a limited representation of all potential participating proteins. DHEA, dehydroepiandrosterone; SHBG, sex hormone-binding globulin; T, testosterone; DHT, dihydrotestosterone; HSP, heat shock protein; TF, transcription factor; ARE, androgen response element.

The DBD of AR is highly conserved and contains two zinc finger domains, through which specificity for DNA binding is determined (Umesono and Evans 1989; Shaffer et al. 2004). The first zinc finger is responsible for interacting with nucleotides within the major groove of DNA, thereby tethering the receptor for the assembly of a transcriptional complex around AR, whereas the second zinc finger coordinates homodimer formation (Shaffer et al. 2004). Notably, a specific sequence of three amino acid residues (Gly-Ser-Val) within the first zinc finger, known as the $\mathrm{P}$ (roximal)-box, is conserved across other steroid receptors, including glucocorticoid receptor (GR), progesterone receptor (PR), and mineralocorticoid receptor (MR) (Umesono and Evans 1989). This homology enables other steroid receptors to recognize response elements in common with $\mathrm{AR}$, which bears potentially significant clinical implications. Recent investigation into postenzalutamide resistance in CRPC has revealed that GR up-regulation may reinstate oncogenic programming through the expression of overlapping, albeit not identical, AR-regulated genes (Arora et al. 2013; Sahu et al. 2013). Around $30 \%$ of prostate cancers express GR, with this proportion increased under androgen-deprived conditions (Szmulewitz et al. 2012). In preclinical models, treatment with enzalutamide upregulates GR expression, which is increased considerably more so following the emergence of enzalutamide resistance. Furthermore, dexamethasone can induce enzalutamide resistance in prostate cancer cell lines, which is subsequently reversed by a glucocorticoid antagonist 
or genetic silencing of GR expression. This newfound reliance on GR, however, presents an inherent challenge for any additional signaling inhibition because, unlike AR, GR signaling is essential for life (Nicolaides et al. 2010). A satisfactory approach to GR pathway blockade may therefore necessitate the identification of suitable downstream targets for inhibition that will not elicit intolerable or life-threatening toxicities (Sharifi 2014; Li et al. 2017).

The NTD contains transcriptional activation function-1 (AF-1), which commands transcriptional activity and is basally suppressed by the LBD (Jenster et al. 1991; Simental et al. 1991). In recent years, a number of truncated AR splice variants (AR-Vs) have been identified and implicated in CRPC (Dehm et al. 2008; Guo et al. 2009; Hu et al. 2009; Sun et al. 2010); these variants all harbor an intact NTD and DBD but reveal notable loss of the carboxy-terminal LBD, leading to the uncoupling of transcriptional control from ligand-dependent induction. It is thought that AR-Vs may emerge through aberrant alternative splicing (Liu et al. 2014) or AR gene rearrangements ( $\mathrm{Li}$ et al. 2011, 2012) to escape antiandrogen therapies that target the LBD. Although more than $20 \mathrm{AR}-\mathrm{Vs}$ have now been confirmed in prostate cancer specimens (Robinson et al. 2015), which show different levels of transcriptional activity and expression (Ware et al. 2014; Lu et al. 2015), AR-V7 is the most commonly detected variant in CRPC (Ware et al. 2014). Truncation of AR-V7 occurs after exon 3 and includes a cryptic exon $3 \mathrm{~b}$ from an intron into the expressed protein (Fig. 2). AR-V7 is constitutively active, and mRNA levels in circulating tumor cells (CTCs) have been recently found to correlate strikingly with resistance to enzalutamide and abiraterone, suggesting that AR-Vs may serve as a promising biomarker for therapeutic response (Antonarakis et al. 2014). Several preclinical models in which AR-V7 is either expressed endogenously with full-length AR (AR-FL) or exogenously in AR-FL-negative cells show an abrogated androgen requirement and resistance to antiandrogens in the presence of AR-V7 (Hu et al. 2009; Mostaghel et al. 2011; Li et al. 2013; Cao et al. 2014). Furthermore, exposure to ADT and
AR-directed therapies may reciprocally induce AR-V7 expression (Watson et al. 2010; Mostaghel et al. 2011). Although it was originally suggested that AR-V7 primarily heterodimerizes with AR-FL to mediate target gene transcription (Watson et al. 2010; Cao et al. 2014), AR-V7 may also alternatively homodimerize to drive AR signaling independently of AR-FL (Chan et al. 2015; Xu et al. 2015). However, in comparison to AR-FL, AR-V levels are generally low (Watson et al. 2010), particularly in tumors treated with new generation hormonal therapies, and expression of AR-FL nearly always co-occurs with the presence of AR-Vs ( $\mathrm{Lu}$ et al. 2015). Thus, whether AR-Vs are a selfsufficient substitute for AR-FL and whether differential changes in oncogenic transcriptional programming can occur in the presence of AR-Vs remains a topic of interest for further investigation ( $\mathrm{Lu}$ et al. 2015).

Advances in our knowledge on AR-Vs in prostate cancer progression and the dynamic structure-function relationships of the different AR domains have unveiled alternative approaches to achieve therapeutic inhibition of AR signaling. Among these are AR-directed agents that do not target the LBD. EPI-506 is an NTD inhibitor that can bind both AR-Vs and AR-FL and is currently under evaluation in phase I clinical trials (NCT02606123) (Maughan and Antonarakis 2015). Other potentially attractive therapeutic targets include the DBD (Dalal et al. 2014) and sites of AR cofactor interaction (Ravindranathan et al. 2013). In summary, our progressive understanding of the potential molecular mechanisms through which AR may drive transcriptional programming continues to guide the development of novel strategies to disrupt AR signaling.

\section{ANDROGEN RECEPTOR COREGULATORS}

Approximately 300 AR coregulators have now been identified (Heemers and Tindall 2007; DePriest et al. 2016), which can coactivate or corepress AR transactivation and are increasingly recognized to do so in a target-gene-specific manner (Marshall et al. 2003; Agoulnik and Weigel 2009; Heemers et al. 2009; Ianculescu 
C. Dai et al.

et al. 2012). Within a large class of proteins with diverse cellular functions and characteristics, these coregulators commonly associate with AR to ensure effective transcription of target genes (Fig. 3) (Heemers and Tindall 2007). Coregulators can alter transcriptional activity through modulation of a variety of processes, including (1) AR stabilization, homodimerization, and nuclear translocation, (2) chromatin remodeling and DNA occupancy, (3) recruitment of general TFs, and (4) priming and assembly of the preinitiation transcriptional complex (Heemers and Tindall 2007; Shiota et al. 2011). Among the prototypical and most wellstudied coregulators is the p160 coactivator family, comprised of three protein members: SRC1, SRC2 (TIF2), and SRC3. These proteins specifically bind to the AR NTD, influencing transactivation through direct histone acetyltransferase activity, as well as through indirect recruitment of secondary coactivators to induce chromatin remodeling (Chakravarti et al. 1996). A common attribute among many coregulators is the ability to enzymatically modify AR and other components within the local molecular environment, such as histones, transcriptional proteins, and other coregulators, through acetylation, methylation, phosphorylation, SUMOylation, and ubiquitination (Heemers and Tindall 2007, 2009). This, in turn, initiates cellular processes such as proliferation and invasion, driving tumor progression. An example of this relationship is underscored by speckle-type POZ protein (SPOP) missense mutations in prostate cancer (Berger et al. 2011; Barbieri et al. 2012; Grasso et al. 2012). SPOP, which is an E3 ubiquitin ligase normally involved in the degradation and turnover of AR as well as SRC3, may incur mutations that lead to increased AR protein levels and liberation of AR-mediated gene transcription (An et al. 2014; Geng et al. 2014). Interestingly, ARVs that lack the hinge region required for interaction with SPOP are resistant to degradation (An et al. 2014). SPOP mutations are common, occurring in up to $11 \%-13 \%$ of primary prostate cancers, and represent a distinct molecular subtype of disease (The Cancer Genome Atlas Research Network 2015).
Androgens have been shown to regulate the expression of $\sim 30 \%$ of coregulators (Heemers et al. 2009, 2010). This response is variable across coregulators and is highly specific to particular AR target genes (Heemers et al. 2009). Furthermore, overexpression of coactivators is associated with increased clinical aggressiveness (Gnanapragasam et al. 2001; Debes et al. 2003; Zhou et al. 2005). The recent development of peptidomimetics (Ravindranathan et al. 2013) and small molecule inhibitors (Wang et al. 2011b, 2014; Asangani et al. 2014), which target these various coregulators offers a promising approach that may yield a new class of therapeutic agents for CRPC. Prototypical examples include SRC-3 and SRC-1 inhibitors (Wang et al. 2011b, 2014), as well as bromodomain and extraterminal (BET) inhibitors, which disrupt target gene activation by preventing the binding of BET subfamily proteins to acetylated chromatin (Asangani et al. 2014, 2016). In addition, the use of innovative molecular screening approaches such as "Chem-seq" —in which biotin-tagged small molecules are captured by ChIP to link candidate compounds to regulated target genes-may increasingly reveal suitable agents to disrupt the transcriptional program of prostate cancer. Overall, efforts to elucidate key AR coregulators have shown an impressive number of potentially actionable proteins involved in the intricate, selective, and dynamic interplay with AR to promote AR signaling (DePriest et al. 2016).

\section{ANDROGEN RECEPTOR ACTION}

The classical model of genomic AR signaling involves the recruitment of the ligand-bound steroid receptor to AR-binding sites to activate the AR transcriptome (Nelson et al. 2002; Dehm and Tindall 2006). A compelling link that underpins AR signaling to prostate tumorigenesis is well illustrated through the occurrence of chromosomal rearrangements that generate novel fusions between the androgen-regulatory elements of TMPRSS2 and ETS family of oncogenes (ERG, ETV1) (Tomlins et al. 2005). TMPRSS2-ERG fusions are the most common molecular alteration in prostate cancer, occur- 
ring in $40 \%-50 \%$ of tumors (Tomlins et al. 2009; The Cancer Genome Atlas Research Network 2015). These fusions are also recognized in isolated high-grade prostatic intraepithelial neoplasia (HGPIN) lesions (Park et al. 2014), lesions associated with cancer (Perner et al. 2007), as well as benign prostatic epithelial cells after extended exposure to DHT (Berger et al. 2011), suggesting that the acquisition of TMPRSS2-ETS fusions is likely an early carcinogenic event. Moreover, some evidence suggests that androgens themselves can provoke nonrandom fusion events (Lin et al. 2009; Mani et al. 2009). However, other instigators such as activation of the PI3K/Akt pathway may be required in the presence of fusions to fully induce malignant transformation (Carver et al. 2009; King et al. 2009).

The collective AR cistrome appears to undergo extensive reprogramming with malignant transformation and disease progression (Wang et al. 2009; Sharma et al. 2013; Pomerantz et al. 2015a). Large-scale bioinformatics and systems-based initiatives to characterize the genomic regions of global AR occupancy have revealed an incredible degree of complexity and variation to AR-responsive gene regulation (Sharma et al. 2013; Mills 2014). In fact, the interfacing of TF networks may critically dictate a particular AR-binding profile, which is distinctly different between normal and tumor tissue (Pomerantz et al. 2015b) and may be perturbed by the presence of external signaling factors such as inflammatory cytokines (Sharma et al. 2013). Considerable differences also exist between the AR-binding profile of cell lines and that of primary tissue, indicating that a set of genes might be selectively activated through in vivo signaling (Sharma et al. 2013). Among TFs most enriched at AR-binding sites is forkhead box A1 (FOXA1), a pioneer factor that globally facilitates AR action through interaction with $\mathrm{AR}$ at the DBD. FOXA1-binding sites are typically found in close proximity to AR-binding sites, with a large amount of overlap between their respective cistromes (Zhao et al. 2014). In experiments, FOXA1 may either augment or antagonize AR signaling depending on the setting (Wang et al. 2011a). Homeobox B13
(HOXB13), a highly lineage-specific factor, which is itself regulated by FOXA1 (McMullin et al. 2010), has also emerged through recognition of its role in hereditable prostate cancer disposition and disease progression (Ewing et al. 2012; Decker and Ostrander 2014). Together, FOXA1 and HOXB13 have been shown to be sufficient in reprogramming the AR cistrome in an immortalized prostate cell line to resemble that of malignancy (Pomerantz et al. 2015a). These findings have highlighted the dynamic and contextually dependent nature of AR binding (Heemers and Tindall 2009).

\section{AR PATHWAY CROSS TALK AND LIGAND- INDEPENDENT ACTIVATION}

Evidence also indicates that various growth factor, cytokine, and nonreceptor tyrosine kinase pathways are activated in prostate cancer (Lamont and Tindall 2011). A number of cell surface receptors including epidermal growth factor receptor (EGFR), interleukin (IL)-6 and IL-8 receptors, insulin-like growth factor 1 (IGF-1) receptor, and Her2/neu have been implicated in cross talk with AR to drive ligandindependent signaling or to sensitize AR to subphysiologic androgen concentrations (Mellinghoff et al. 2004; Guo et al. 2006; Ponguta et al. 2008; Dutt and Gao 2009). Intracellular kinases such as mitogen-activated protein kinase (MAPK), as well as its effectors Src and ERK1/2, and PI3K/Akt have also been shown to drive prostate cancer progression (Guo et al. 2006). Many of these proteins are downstream elements of nongenomic AR signaling, which can mediate a proliferation response typically within minutes of ligand stimulation (Lösel and Wehling 2003; Liao et al. 2013) via cytoplasmic and lipid raft-associated AR (Pedram et al. 2007). Although sizable preclinical data exist to suggest a therapeutic benefit with pharmacologically inhibiting these pathways, clinical results have been mostly disappointing to date (Ziada et al. 2004; de Bono et al. 2007; Araujo et al. 2013). Overall, these signaling molecules may represent a larger coordinated and possibly redundant network of signal transduction path- 
C. Dai et al.

ways that act in concert with AR signaling to promote key neoplastic processes.

\section{CONCLUDING REMARKS}

Since the work of Huggins and Hodges, major advances have contributed to our understanding of the AR signaling axis in the pathogenesis of prostate cancer. With this also comes a greater appreciation for the complexity of prereceptor and postreceptor AR regulation. Major milestones were achieved with the introduction of abiraterone and enzalutamide in the treatment of CRPC, which has resulted in a significant paradigm shift and renewed interest in intratumoral androgen suppression. However, onset of resistance to these second-generation agents has also galvanized new directions to investigate the mechanisms that may promote this escape. Evolving molecular approaches have revealed key insights into the structural basis of AR function and the dynamic, context-dependent nature of AR transcriptional control. The hope is that these ongoing efforts will translate into greater precision in AR targeting and novel therapeutic options in the near future for men with prostate cancer.

\section{ACKNOWLEDGMENTS}

This work is supported by funding from the Howard Hughes Medical Institute Medical Fellows Program (C.D.), National Cancer Institute (CA166440 to H.H. and R01CA168899, R01CA172382, R01CA190289 to N.S.), Prostate Cancer Foundation (Young Investigator Award to H.H. and Challenge Award to N.S.), Howard Hughes Medical Institute Physician-Scientist Early Career Award (N.S.), American Cancer Society Research Scholar Award (12-038-01CCE to N.S), and Department of Defense PCRP award W81XWH-16-1-0404 (H.H.).

\section{REFERENCES}

Adeniji AO, Chen M, Penning TM. 2013. AKR1C3 as a target in castrate resistant prostate cancer. J Steroid Biochem Mol Biol 137: 136-149.
Agoulnik IU, Weigel NL. 2009. Coactivator selective regulation of androgen receptor activity. Steroids 74: 669-674.

An J, Wang C, Deng Y, Yu L, Huang H. 2014. Destruction of full-length androgen receptor by wild-type SPOP, but not prostate-cancer-associated mutants. Cell Rep 6: 657-669.

Andersson S, Berman DM, Jenkins EP, Russell DW. 1991. Deletion of steroid $5 \alpha$-reductase 2 gene in male pseudohermaphroditism. Nature 354: 159-161.

Antonarakis ES, Lu C, Wang H, Luber B, Nakazawa M, Roeser JC, Chen Y, Mohammad TA, Chen Y, Fedor HL, et al. 2014. AR-V7 and resistance to enzalutamide and abiraterone in prostate cancer. N Engl J Med 371: 1028-1038.

Araujo JC, Trudel GC, Saad F, Armstrong AJ, Yu EY, Bellmunt J, Wilding G, McCaffrey J, Serrano SV, Matveev VB, et al. 2013. Docetaxel and dasatinib or placebo in men with metastatic castration-resistant prostate cancer (READY): A randomised, double-blind phase 3 trial. Lancet Oncol 14: 1307-1316.

Arora VK, Schenkein E, Murali R, Subudhi SK, Wongvipat J, Balbas MD, Shah N, Cai L, Efstathiou E, Logothetis C, et al. 2013. Glucocorticoid receptor confers resistance to antiandrogens by bypassing androgen receptor blockade. Cell 155: 1309-1322.

Asangani IA, Dommeti VL, Wang X, Malik R, Cieslik M, Yang R, Escara-Wilke J, Wilder-Romans K, Dhanireddy S, Engelke C, et al. 2014. Therapeutic targeting of BET bromodomain proteins in castration-resistant prostate cancer. Nature 510: 278-282.

Asangani IA, Wilder-Romans K, Dommeti VL, Krishnamurthy PM, Apel IJ, Escara-Wilke J, Plymate SR, Navone NM, Wang S, Feng FY, et al. 2016. BET bromodomain inhibitors enhance efficacy and disrupt resistance to AR antagonists in the treatment of prostate cancer. Mol Cancer Res 14: 324-331.

Askew EB, Gampe RT, Stanley TB, Faggart JL, Wilson EM. 2007. Modulation of androgen receptor activation function 2 by testosterone and dihydrotestosterone. J Biol Chem 282: 25801-25816.

Attard G, Swennenhuis JF, Olmos D, Reid AHM, Vickers E, A'Hern R, Levink R, Coumans F, Moreira J, Riisnaes R, et al. 2009. Characterization of ERG, AR and PTEN gene status in circulating tumor cells from patients with castration-resistant prostate cancer. Cancer Res 69: 2912-2918.

Attard G, Reid AHM, Auchus RJ, Hughes BA, Cassidy AM, Thompson E, Oommen NB, Folkerd E, Dowsett M, Arlt W, et al. 2012. Clinical and biochemical consequences of CYP17A1 inhibition with abiraterone given with and without exogenous glucocorticoids in castrate men with advanced prostate cancer. J Clin Endocrinol Metab 97: 507-516.

Azzouni F, Mohler J. 2012. Role of $5 \alpha$-reductase inhibitors in prostate cancer prevention and treatment. Urology 79: 1197-1205.

Balbas MD, Evans MJ, Hosfield DJ, Wongvipat J, Arora VK, Watson PA, Chen Y, Greene GL, Shen Y, Sawyers CL. 2013. Overcoming mutation-based resistance to antiandrogens with rational drug design. eLife 2: e00499.

Barbieri CE, Baca SC, Lawrence MS, Demichelis F, Blattner M, Theurillat JP, White TA, Stojanov P, Van Allen E, Stransky N, et al. 2012. Exome sequencing identifies recurrent SPOP, FOXA1 and MED12 mutations in prostate cancer. Nat Genet 44: 685-689. 
Beer TM, Armstrong AJ, Rathkopf DE, Loriot Y, Sternberg CN, Higano CS, Iversen P, Bhattacharya S, Carles J, Chowdhury S, et al. 2014. Enzalutamide in metastatic prostate cancer before chemotherapy. $N$ Engl J Med 371: 424-433.

Berger MF, Lawrence MS, Demichelis F, Drier Y, Cibulskis K, Sivachenko AY, Sboner A, Esgueva R, Pflueger D, Sougnez C, et al. 2011. The genomic complexity of primary human prostate cancer. Nature 470: 214-220.

Berrevoets CA, Doesburg P, Steketee K, Trapman J, Brinkmann AO. 1998. Functional interactions of the AF-2 activation domain core region of the human androgen receptor with the amino-terminal domain and with the transcriptional coactivator TIF2 (transcriptional intermediary factor2). Mol Endocrinol 12: 1172-1183.

Bruchovsky N, Wilson JD. 1968. The intranuclear binding of testosterone and 5 - $\alpha$-androstan-17- $\beta$-ol-3-one by rat prostate. J Biol Chem 243: 5953-5960.

Buchanan G, Greenberg NM, Scher HI, Harris JM, Marshall VR, Tilley WD. 2001. Collocation of androgen receptor gene mutations in prostate cancer. Clin Cancer Res 7: 1273-1281.

Byrns MC, Jin Y, Penning TM. 2011. Inhibitors of type 5 17ß-hydroxysteroid dehydrogenase (AKR1C3): Overview and structural insights. J Steroid Biochem Mol Biol 125: 95-104.

Cao B, Qi Y, Zhang G, Xu D, Zhan Y, Alvarez X, Guo Z, Fu X, Plymate SR, Sartor O, et al. 2014. Androgen receptor splice variants activating the full-length receptor in mediating resistance to androgen-directed therapy. Oncotarget 5: 1646-1656.

Carver BS, Tran J, Gopalan A, Chen Z, Shaikh S, Carracedo A, Alimonti A, Nardella C, Varmeh S, Scardino PT, et al. 2009. Aberrant ERG expression cooperates with loss of PTEN to promote cancer progression in the prostate. Nat Genet 41: 619-624.

Chakravarti D, LaMorte VJ, Nelson MC, Nakajima T, Schulman IG, Juguilon H, Montminy M, Evans RM. 1996. Role of CBP/P300 in nuclear receptor signalling. Nature 383: 99-103.

Chan SC, Selth LA, Li Y, Nyquist MD, Miao L, Bradner JE, Raj GV, Tilley WD, Dehm SM. 2015. Targeting chromatin binding regulation of constitutively active AR variants to overcome prostate cancer resistance to endocrine-based therapies. Nucleic Acids Res 43: 5880-5897.

Chang KH, Sharifi N. 2012. Prostate cancer-from steroid transformations to clinical translation. Nat Rev Urol 9: $721-724$.

Chang CS, Kokontis J, Liao ST. 1988. Molecular cloning of human and rat complementary DNA encoding androgen receptors. Science 240: 324-326.

Chang K-H, Li R, Papari-Zareei M, Watumull L, Zhao YD, Auchus RJ, Sharifi N. 2011. Dihydrotestosterone synthesis bypasses testosterone to drive castration-resistant prostate cancer. Proc Natl Acad Sci 108: 13728-13733.

Chang KH, Li R, Kuri B, Lotan Y, Roehrborn CG, Liu J, Vessella R, Nelson PS, Kapur P, Guo X, et al. 2013. A gain-of-function mutation in DHT synthesis in castration-resistant prostate cancer. Cell 154: 1074-1084.

Claessens F, Verrijdt G, Schoenmakers E, Haelens A, Peeters B, Verhoeven G, Rombauts W. 2001. Selective DNA binding by the androgen receptor as a mechanism for hor- mone-specific gene regulation. J Steroid Biochem Mol Biol 76: $23-30$

Claessens F, Denayer S, Van Tilborgh N, Kerkhofs S, Helsen C, Haelens A. 2008. Diverse roles of androgen receptor (AR) domains in AR-mediated signaling. Nucl Recept Signal 6: e008.

Culig Z, Hobisch A, Cronauer MV, Cato AC, Hittmair A, Radmayr C, Eberle J, Bartsch G, Klocker H. 1993. Mutant androgen receptor detected in an advanced-stage prostatic carcinoma is activated by adrenal androgens and progesterone. Mol Endocrinol 7: 1541-1550.

Culig Z, Hoffmann J, Erdel M, Eder IE, Hobisch A, Hittmair A, Bartsch G, Utermann G, Schneider MR, Parczyk K, et al. 1999. Switch from antagonist to agonist of the androgen receptor bicalutamide is associated with prostate tumour progression in a new model system. BrJ Cancer 81: 242-251.

Dalal K, Roshan-Moniri M, Sharma A, Li H, Ban F, Hassona MD, Hessein M, Hsing M, Singh K, LeBlanc E, et al. 2014. Selectively targeting the DNA-binding domain of the androgen receptor as a prospective therapy for prostate cancer. J Biol Chem 289: 26417-26429.

Debes JD, Sebo TJ, Lohse CM, Murphy LM, Haugen DAL, Tindall DJ. 2003. p300 in prostate cancer proliferation and progression. Cancer Res 63: 7638-7640.

de Bono JS, Bellmunt J, Attard G, Droz JP, Miller K, Flechon A, Sternberg C, Parker C, Zugmaier G, Hersberger-Gimenez V, et al. 2007. Open-label phase II study evaluating the efficacy and safety of two doses of pertuzumab in castrate chemotherapy-naïve patients with hormone-refractory prostate cancer. J Clin Oncol 25: 257-262.

de Bono JS, Logothetis CJ, Molina A, Fizazi K, North S, Chu L, Chi KN, Jones RJ, Goodman OB, Saad F, et al. 2011. Abiraterone and increased survival in metastatic prostate cancer. N Engl J Med 364: 1995-2005.

Decker B, Ostrander EA. 2014. Dysregulation of the homeobox transcription factor gene HOXB13: Role in prostate cancer. Pharmgenomics Pers Med 7: 193-201.

Dehm SM, Tindall DJ. 2006. Molecular regulation of androgen action in prostate cancer. J Cell Biochem 99: 333-344.

Dehm SM, Schmidt LJ, Heemers HV, Vessella RL, Tindall DJ. 2008. Splicing of a novel androgen receptor exon generates a constitutively active androgen receptor that mediates prostate cancer therapy resistance. Cancer Res 68: $5469-5477$.

Dellis A, Papatsoris AG. 2016. Phase I and II therapies targeting the androgen receptor for the treatment of castration resistant prostate cancer. Expert Opin Investig Drugs 1-11.

DePriest AD, Fiandalo MV, Schlanger S, Heemers F, Mohler JL, Liu S, Heemers HV. 2016. Regulators of androgen action resource: A one-stop shop for the comprehensive study of androgen receptor action. Database (Oxford) doi: 10.1093/database/bav125.

Deslypere JP, Young M, Wilson JD, McPhaul MJ. 1992. Testosterone and $5 \alpha$-dihydrotestosterone interact differently with the androgen receptor to enhance transcription of the MMTV-CAT reporter gene. Mol Cell Endocrinol 88: 15-22.

Doesburg P, Kuil CW, Berrevoets CA, Steketee K, Faber PW, Mulder E, Brinkmann AO, Trapman J. 1997. Functional in vivo interaction between the amino-terminal, transactivation domain and the ligand binding domain of the androgen receptor. Biochemistry 36: 1052-1064. 
C. Dai et al.

Dunn JF, Nisula BC, Rodbard D. 1981. Transport of steroid hormones: Binding of 21 endogenous steroids to both testosterone-binding globulin and corticosteroid-binding globulin in human plasma. J Clin Endocrinol Metab 53: $58-68$.

Dutt SS, Gao AC. 2009. Molecular mechanisms of castration-resistant prostate cancer progression. Future Oncol 5: $1403-1413$.

Evaul K, Li R, Papari-Zareei M, Auchus RJ, Sharifi N. 2010. $3 \beta$-hydroxysteroid dehydrogenase is a possible pharmacological target in the treatment of castration-resistant prostate cancer. Endocrinology 151: 3514-3520.

Ewing CM, Ray AM, Lange EM, Zuhlke KA, Robbins CM, Tembe WD, Wiley KE, Isaacs SD, Johng D, Wang Y, et al. 2012. Germline mutations in HOXB13 and prostate-cancer risk. N Engl J Med 366: 141-149.

Ferraldeschi R, Welti J, Luo J, Attard G, de Bono JS. 2015 Targeting the androgen receptor pathway in castrationresistant prostate cancer: Progresses and prospects. Oncogene 34: 1745-1757.

Fiandalo MV, Wilton J, Mohler JL. 2014. Roles for the backdoor pathway of androgen metabolism in prostate cancer response to castration and drug treatment. Int J Biol Sci 10: $596-601$.

Fleshner NE, Lucia MS, Egerdie B, Aaron L, Eure G, Nandy I, Black L, Rittmaster RS. 2012. Dutasteride in localised prostate cancer management: The REDEEM randomised, double-blind, placebo-controlled trial. Lancet 379: 1103-1111.

Forti G, Salerno R, Moneti G, Zoppi S, Fiorelli G, Marinon T, Natali A, Costantini A, Serio M, Martini L. 1989. Three-month treatment with a long-acting gonadotropin-releasing hormone agonist of patients with benign prostatic hyperplasia: Effects on tissue androgen concentration, $5 \alpha$-reductase activity and androgen receptor content. J Clin Endocrinol Metab 68: 461-468.

Geissler WM, Davis DL, Wu L, Bradshaw KD, Patel S, Mendonca BB, Elliston KO, Wilson JD, Russell DW, Andersson S. 1994. Male pseudohermaphroditism caused by mutations of testicular $17 \beta$-hydroxysteroid dehydrogenase 3. Nat Genet 7: 34-39.

Geller J, Albert J, Loza D, Geller S, Stoeltzing W, de la Vega D. 1978. DHT concentrations in human prostate cancer tissue. J Clin Endocrinol Metab 46: 440-444.

Gelmann EP. 2002. Molecular biology of the androgen receptor. J Clin Oncol 20: 3001-3015.

Geng C, Rajapakshe K, Shah SS, Shou J, Eedunuri VK, Foley C, Fiskus W, Rajendran M, Chew SA, Zimmermann M, et al. 2014. Androgen receptor is the key transcriptional mediator of the tumor suppressor SPOP in prostate cancer. Cancer Res 74: 5631-5643.

Gnanapragasam VJ, Leung HY, Pulimood AS, Neal DE, Robson CN. 2001. Expression of RAC 3, a steroid hormone receptor co-activator in prostate cancer. $\mathrm{BrJ} \mathrm{Cancer}$ 85: 1928-1936.

Grasso CS, Wu Y-M, Robinson DR, Cao X, Dhanasekaran SM, Khan AP, Quist MJ, Jing X, Lonigro RJ, Brenner JC, et al. 2012. The mutational landscape of lethal castrationresistant prostate cancer. Nature 487: 239-243.

Gregory CW, Hamil KG, Kim D, Hall SH, Pretlow TG, Mohler JL, French FS. 1998. Androgen receptor expression in androgen-independent prostate cancer is associated with increased expression of androgen-regulated genes. Cancer Res 58: 5718-5724.

Gregory CW, Johnson RT, Mohler JL, French FS, Wilson EM. 2001. Androgen receptor stabilization in recurrent prostate cancer is associated with hypersensitivity to low androgen. Cancer Res 61: 2892-2898.

Griffin JE. 1992. Androgen resistance-The clinical and molecular spectrum. N Engl J Med 326: 611-618.

Guo Z, Dai B, Jiang T, Xu K, Xie Y, Kim O, Nesheiwat I, Kong X, Melamed J, Handratta VD, et al. 2006. Regulation of androgen receptor activity by tyrosine phosphorylation. Cancer Cell 10: 309-319.

Guo Z, Yang X, Sun F, Jiang R, Linn DE, Chen H, Chen H, Kong X, Melamed J, Tepper CG, et al. 2009. A novel androgen receptor splice variant is up-regulated during prostate cancer progression and promotes androgen depletion-resistant growth. Cancer Res 69: 2305-2313.

Hara T, Miyazaki J, Araki H, Yamaoka M, Kanzaki N, Kusaka M, Miyamoto M. 2003. Novel mutations of androgen receptor: A possible mechanism of bicalutamide withdrawal syndrome. Cancer Res 63: 149-153.

He B, Kemppainen JA, Wilson EM. 2000. FXXLF and WXXLF sequences mediate the $\mathrm{NH} 2$-terminal interaction with the ligand binding domain of the androgen receptor. J Biol Chem 275: 22986-22994.

He B, Minges JT, Lee LW, Wilson EM. 2002. The FXXLF motif mediates androgen receptor-specific interactions with coregulators. J Biol Chem 277: 10226-10235.

Hearn JW, AbuAli G, Reichard CA, Reddy CA, Magi-Galluzzi C, Chang K-H, Carlson R, Rangel L, Reagan K, Davis BJ, et al. 2016. HSD3B1 and resistance to androgen deprivation therapy in prostate cancer: A multi-cohort study. Lancet Oncol 17: 1435-1444.

Heemers HV. 2014. Targeting androgen receptor action for prostate cancer treatment: Does the post-receptor level provide novel opportunities? Int J Biol Sci 10: 576-587.

Heemers HV, Tindall DJ. 2007. Androgen receptor (AR) coregulators: A diversity of functions converging on and regulating the AR transcriptional complex. Endocr Rev 28: 778-808.

Heemers HV, Tindall DJ. 2009. Unraveling the complexities of androgen receptor signaling in prostate cancer cells. Cancer Cell 15: 245-247.

Heemers HV, Regan KM, Schmidt LJ, Anderson SK, Ballman KV, Tindall DJ. 2009. Androgen modulation of coregulator expression in prostate cancer cells. Mol Endocrinol 23: 572-583.

Heemers HV, Schmidt LJ, Kidd E, Raclaw KA, Regan KM, Tindall DJ. 2010. Differential regulation of steroid nuclear receptor coregulator expression between normal and neoplastic prostate epithelial cells. Prostate 70: 959-970.

Heery DM, Kalkhoven E, Hoare S, Parker MG. 1997. A signature motif in transcriptional co-activators mediates binding to nuclear receptors. Nature 387: 733-736.

Hofland J, van Weerden WM, Dits NFJ, Steenbergen J, van Leenders GJLH, Jenster G, Schröder FH, de Jong FH. 2010. Evidence of limited contributions for intratumoral steroidogenesis in prostate cancer. Cancer Res 70: 12561264.

Holzbeierlein J, Lal P, LaTulippe E, Smith A, Satagopan J, Zhang L, Ryan C, Smith S, Scher H, Scardino P, et al. 
2004. Gene expression analysis of human prostate carcinoma during hormonal therapy identifies androgen-responsive genes and mechanisms of therapy resistance. Am J Pathol 164: 217-227.

Hu R, Dunn TA, Wei S, Isharwal S, Veltri RW, Humphreys E, Han M, Partin AW, Vessella RL, Isaacs WB, et al. 2009. Ligand-independent androgen receptor variants derived from splicing of cryptic exons signify hormone-refractory prostate cancer. Cancer Res 69: 16-22.

Huggins C, Hodges CV. 1941. Studies on prostatic cancer. I: The effect of castration, of estrogen and of androgen injection on serum phosphatases in metastatic carcinoma of the prostate. Cancer Res 1: 293-297.

Ianculescu I, Wu DY, Siegmund KD, Stallcup MR. 2012. Selective roles for cAMP response element-binding protein binding protein and $\mathrm{p} 300$ protein as coregulators for androgen-regulated gene expression in advanced prostate cancer cells. J Biol Chem 287: 4000-4013.

Imperato-McGinley J, Guerrero L, Gautier T, Peterson RE. 1974. Steroid $5 \alpha$-reductase deficiency in man: An inherited form of male pseudohermaphroditism. Science 186: 1213-1215.

Jenster G, van der Korput HA, van Vroonhoven C, van der Kwast TH, Trapman J, Brinkmann AO. 1991. Domains of the human androgen receptor involved in steroid binding, transcriptional activation, and subcellular localization. Mol Endocrinol 5: 1396-1404.

Kaku N, Matsuda K, Tsujimura A, Kawata M. 2008. Characterization of nuclear import of the domain-specific androgen receptor in association with the importin $\alpha /$ $\beta$ and Ran-Guanosine 5' -triphosphate systems. Endocrinology 149: 3960-3969.

King JC, Xu J, Wongvipat J, Hieronymus $\mathrm{H}$, Carver BS, Leung DH, Taylor BS, Sander C, Cardiff RD, Couto SS, et al. 2009. Cooperativity of TMPRSS2-ERG with PI3kinase pathway activation in prostate oncogenesis. Nat Genet 41: 524-526.

Knudsen KE. 2014. Hormone whodunit: Clues for solving the case of intratumor androgen production. Clin Cancer Res 20: 5343-5345.

Knudsen KE, Scher HI. 2009. Starving the addiction: New opportunities for durable suppression of AR signaling in prostate cancer. Clin Cancer Res 15: 4792-4798.

Labrie F, Dupont A, Simard J, Luu-The V, Bélanger A. 1993. Intracrinology: The basis for the rational design of endocrine therapy at all stages of prostate cancer. Eur Urol 24: 94-105.

Lamont KR, Tindall DJ. 2011. Minireview: Alternative activation pathways for the androgen receptor in prostate cancer. Mol Endocrinol 25: 897-907.

Li Y, Alsagabi M, Fan D, Bova GS, Tewfik AH, Dehm SM. 2011. Intragenic rearrangement and altered RNA splicing of the androgen receptor in a cell-based model of prostate cancer progression. Cancer Res 71: 2108-2117.

Li Y, Hwang TH, Oseth LA, Hauge A, Vessella RL, Schmechel SC, Hirsch B, Beckman KB, Silverstein KA, Dehm SM. 2012. AR intragenic deletions linked to androgen receptor splice variant expression and activity in models of prostate cancer progression. Oncogene 31: 4759-4767.

Li Y, Chan SC, Brand LJ, Hwang TH, Silverstein KAT, Dehm SM. 2013. Androgen receptor splice variants mediate en- zalutamide resistance in castration-resistant prostate cancer cell lines. Cancer Res 73: 483-489.

Li Z, Bishop AC, Alyamani M, Garcia JA, Dreicer R, Bunch D, Liu J, Upadhyay SK, Auchus RJ, Sharifi N. 2015. Conversion of abiraterone to $\mathrm{D} 4 \mathrm{~A}$ drives anti-tumour activity in prostate cancer. Nature 523: 347-351.

Li Z, Alyamani M, Li J, Rogacki K, Abazeed M, Upadhyay SK, Balk SP, Taplin ME, Auchus RJ, Sharifi N. 2016. Redirecting abiraterone metabolism to fine-tune prostate cancer anti-androgen therapy. Nature 533: 547-551.

Li J, Alyamani M, Zhang A, Chang K-H, Berk M, Li Z, Zhu Z, Petro M, Magi-Galluzzi C, Taplin M-E, et al. 2017. Aberrant corticosteroid metabolism in tumor cells enables GR takeover in enzalutamide resistant prostate cancer. eLife doi: 10.7554/eLife.20183.

Liao RS, Ma S, Miao L, Li R, Yin Y, Raj GV. 2013. Androgen receptor-mediated non-genomic regulation of prostate cancer cell proliferation. Transl Androl Urol 2: 187-196.

Lin C, Yang L, Tanasa B, Hutt K, Ju B, Ohgi K, Zhang J, Rose DW, Fu XD, Glass CK, et al. 2009. Nuclear receptor-induced chromosomal proximity and DNA breaks underlie specific translocations in cancer. Cell 139: 1069-1083.

Liu LL, Xie N, Sun S, Plymate S, Mostaghel E, Dong X. 2014. Mechanisms of the androgen receptor splicing in prostate cancer cells. Oncogene 33: 3140-3150.

Lösel R, Wehling M. 2003. Nongenomic actions of steroid hormones. Nat Rev Mol Cell Biol 4: 46-56.

Lu J, Van der Steen T, Tindall DJ. 2015. Are androgen receptor variants a substitute for the full-length receptor? Nat Rev Urol 12: 137-144.

Lubahn DB, Brown TR, Simental JA, Higgs HN, Migeon CJ, Wilson EM, French FS. 1989. Sequence of the intron/ exon junctions of the coding region of the human androgen receptor gene and identification of a point mutation in a family with complete androgen insensitivity. Proc Natl Acad Sci 86: 9534-9538.

Mani R-S, Tomlins SA, Callahan K, Ghosh A, Nyati MK, Varambally S, Palanisamy N, Chinnaiyan AM. 2009. Induced chromosomal proximity and gene fusions in prostate cancer. Science 326: 1230.

Marks LS. 2004. $5 \alpha$-reductase: History and clinical importance. Rev Urol 6: S11-S21.

Marshall TW, Link KA, Petre-Draviam CE, Knudsen KE. 2003. Differential requirement of SWI/SNF for androgen receptor activity. J Biol Chem 278: 30605-30613.

Maughan BL, Antonarakis ES. 2015. Clinical relevance of androgen receptor splice variants in castration-resistant prostate cancer. Curr Treat Options Oncol 16: 57.

McMullin RP, Dobi A, Mutton LN, Orosz A, Maheshwari S, Shashikant CS, Bieberich CJ. 2010. A FOXA1-binding enhancer regulates Hoxb13 expression in the prostate gland. Proc Natl Acad Sci 107: 98-103.

Mellinghoff IK, Vivanco I, Kwon A, Tran C, Wongvipat J, Sawyers CL. 2004. HER2/neu kinase-dependent modulation of androgen receptor function through effects on DNA binding and stability. Cancer Cell 6: 517-527.

Mills IG. 2014. Maintaining and reprogramming genomic androgen receptor activity in prostate cancer. Nat Rev Cancer 14: 187-198.

Mohler JL. 2008. Castration-recurrent prostate cancer is not androgen-independent. Adv Exp Med Biol 617: 223-234. 
C. Dai et al.

Mohler JL, Gregory CW, Ford OH, Kim D, Weaver CM, Petrusz P, Wilson EM, French FS. 2004. The androgen axis in recurrent prostate cancer. Clin Cancer Res 10: $440-448$.

Mohler JL, Armstrong AJ, Bahnson RR, Boston B, Busby JE, D'Amico AV, Eastham JA, Enke CA, Farrington T, Higano CS, et al. 2012. Prostate cancer, Version 3.2012: Featured updates to the NCCN guidelines. J Natl Compr Canc Netw 10: 1081-107.

Montgomery RB, Mostaghel EA, Vessella R, Hess DL, Kalhorn TF, Higano CS, True LD, Nelson PS. 2008. Maintenance of intratumoral androgens in metastatic prostate cancer: A mechanism for castration-resistant tumor growth. Cancer Res 68: 4447-4454.

Mostaghel EA. 2013. Steroid hormone synthetic pathways in prostate cancer. Transl Androl Urol 2: 212-227.

Mostaghel EA. 2014a. Abiraterone in the treatment of metastatic castration-resistant prostate cancer. Cancer Manag Res 6: 39-51.

Mostaghel EA. 2014b. Beyond T and DHT—Novel steroid derivatives capable of wild type androgen receptor activation. Int J Biol Sci 10: 602-613.

Mostaghel EA, Page ST, Lin DW, Fazli L, Coleman IM, True LD, Knudsen B, Hess DL, Nelson CC, Matsumoto AM, et al. 2007. Intraprostatic androgens and androgen-regulated gene expression persist after testosterone suppression: Therapeutic implications for castration-resistant prostate cancer. Cancer Res 67: 5033-5041.

Mostaghel EA, Marck BT, Plymate SR, Vessella RL, Balk S, Matsumoto AM, Nelson PS, Montgomery RB. 2011. Resistance to CYP17A1 inhibition with abiraterone in castration-resistant prostate cancer: Induction of steroidogenesis and androgen receptor splice variants. Clin Cancer Res 17: 5913-5925.

Mostaghel EA, Nelson PS, Lange P, Lin DW, Taplin ME, Balk S, Ellis W, Kantoff P, Marck B, Tamae D, et al. 2014 Targeted androgen pathway suppression in localized prostate cancer: A pilot study. J Clin Oncol 32: 229-237.

Nakamura Y, Hornsby PJ, Casson P, Morimoto R, Satoh F, Xing Y, Kennedy MR, Sasano H, Rainey WE. 2009. Type 5 17ß-hydroxysteroid dehydrogenase (AKR1C3) contributes to testosterone production in the adrenal reticularis. J Clin Endocrinol Metab 94: 2192-2198.

Nelson PS, Clegg N, Arnold H, Ferguson C, Bonham M, White J, Hood L, Lin B. 2002. The program of androgen-responsive genes in neoplastic prostate epithelium. Proc Natl Acad Sci 99: 11890-11895.

Ni L, Llewellyn R, Kesler CT, Kelley JB, Spencer A, Snow CJ, Shank L, Paschal BM. 2013. Androgen induces a switch from cytoplasmic retention to nuclear import of the androgen receptor. Mol Cell Biol 33: 4766-4778.

Nicolaides NC, Galata Z, Kino T, Chrousos GP, Charmandari E. 2010. The human glucocorticoid receptor: Molecular basis of biologic function. Steroids 75: 1-12.

Nishiyama T. 2014. Serum testosterone levels after medical or surgical androgen deprivation: A comprehensive review of the literature. Urol Oncol 32: 38.e17-28.

Nishiyama T, Hashimoto Y, Takahashi K. 2004. The influence of androgen deprivation therapy on dihydrotestosterone levels in the prostatic tissue of patients with prostate cancer. Clin Cancer Res 10: 7121-7126.
Nuclear Receptors Nomenclature Committee. 1999. A unified nomenclature system for the nuclear receptor superfamily. Cell 97: 161-163.

Ozanne DM, Brady ME, Cook S, Gaughan L, Neal DE, Robson CN. 2000. Androgen receptor nuclear translocation is facilitated by the F-actin cross-linking protein filamin. Mol Endocrinol 14: 1618-1626.

Page ST, Lin DW, Mostaghel EA, Hess DL, True LD, Amory JK, Nelson PS, Matsumoto AM, Bremner WJ. 2006. Persistent intraprostatic androgen concentrations after medical castration in healthy men. J Clin Endocrinol Metab 91: 3850-3856.

Page ST, Lin DW, Mostaghel EA, Marck BT, Wright JL, Wu J, Amory JK, Nelson PS, Matsumoto AM. 2011. Dihydrotestosterone administration does not increase intraprostatic androgen concentrations or alter prostate androgen action in healthy men: A randomized-controlled trial. J Clin Endocrinol Metab 96: 430-437.

Park K, Dalton JT, Narayanan R, Barbieri CE, Hancock ML, Bostwick DG, Steiner MS, Rubin MA. 2014. TMPRSS2: $E R G$ gene fusion predicts subsequent detection of prostate cancer in patients with high-grade prostatic intraepithelial neoplasia. J Clin Oncol 32: 206-211.

Pedram A, Razandi M, Sainson RCA, Kim JK, Hughes CC, Levin ER. 2007. A conserved mechanism for steroid receptor translocation to the plasma membrane. J Biol Chem 282: 22278-22288.

Perner S, Mosquera JM, Demichelis F, Hofer MD, Paris PL, Simko J, Collins C, Bismar TA, Chinnaiyan AM, De Marzo AM, et al. 2007. TMPRSS2-ERG fusion prostate cancer: An early molecular event associated with invasion. Am J Surg Pathol 31: 882-888.

Pomerantz MM, Li F, Takeda DY, Lenci R, Chonkar A, Chabot M, Cejas P, Vazquez F, Cook J, Shivdasani RA, et al. 2015a. The androgen receptor cistrome is extensively reprogrammed in human prostate tumorigenesis. $\mathrm{Nat} \mathrm{Ge}$ net 47: 1346-1351.

Pomerantz MM, Li F, Takeda DY, Lenci R, Chonkar A, Chabot M, Cejas P, Vazquez F, Cook J, Shivdasani RA, et al. 2015b. The androgen receptor cistrome is extensively reprogrammed in human prostate tumorigenesis. $\mathrm{Nat} \mathrm{Ge}$ net 47: 1346-1351.

Ponguta LA, Gregory CW, French FS, Wilson EM. 2008. Site-specific androgen receptor serine phosphorylation linked to epidermal growth factor-dependent growth of castration-recurrent prostate cancer. J Biol Chem 283: 20989-21001.

Ravindranathan P, Lee TK, Yang L, Centenera MM, Butler L, Tilley WD, Hsieh JT, Ahn JM, Raj GV. 2013. Peptidomimetic targeting of critical androgen receptor-coregulator interactions in prostate cancer. Nat Commun 4: 1923.

Rittmaster RS. 1997. $5 \alpha$-reductase inhibitors. J Androl 18: 582-587.

Rittmaster R, Hahn RG, Ray P, Shannon JB, Wurzel R. 2008. Effect of dutasteride on intraprostatic androgen levels in men with benign prostatic hyperplasia or prostate cancer. Urology 72: 808-812.

Robinson D, Van Allen EM, Wu YM, Schultz N, Lonigro RJ, Mosquera JM, Montgomery B, Taplin ME, Pritchard CC, Attard G, et al. 2015. Integrative clinical genomics of advanced prostate cancer. Cell 161: 1215-1228. 
Rosner W, Hryb DJ, Khan MS, Nakhla AM, Romas NA. 1991. Sex hormone-binding globulin: Anatomy and physiology of a new regulatory system. J Steroid Biochem Mol Biol 40: 813-820.

Ruizeveld de Winter JA, Janssen PJ, Sleddens HM, VerleunMooijman MC, Trapman J, Brinkmann AO, Santerse AB, Schröder FH, van der Kwast TH. 1994. Androgen receptor status in localized and locally progressive hormone refractory human prostate cancer. Am J Pathol 144: 735-746.

Russell DW, Wilson JD. 1994. Steroid $5 \alpha$-reductase: Two genes/two enzymes. Annu Rev Biochem 63: 25-61.

Ryan CJ, Tindall DJ. 2011. Androgen receptor rediscovered: The new biology and targeting the androgen receptor therapeutically. J Clin Oncol 29: 3651-3658.

Ryan CJ, Smith A, Lal P, Satagopan J, Reuter V, Scardino P, Gerald W, Scher HI. 2006. Persistent prostate-specific antigen expression after neoadjuvant androgen depletion: An early predictor of relapse or incomplete androgen suppression. Urology 68: 834-839.

Ryan CJ, Smith MR, Fizazi K, Saad F, Mulders PFA, Sternberg CN, Miller K, Logothetis CJ, Shore ND, Small EJ, et al. 2015. Abiraterone acetate plus prednisone versus placebo plus prednisone in chemotherapy-naïve men with metastatic castration-resistant prostate cancer (COUAA-302): Final overall survival analysis of a randomised, double-blind, placebo-controlled phase 3 study. Lancet Oncol 16: 152-160.

Sadi MV, Walsh PC, Barrack ER. 1991. Immunohistochemical study of androgen receptors in metastatic prostate cancer. Comparison of receptor content and response to hormonal therapy. Cancer 67: 3057-3064.

Sahu B, Laakso M, Pihlajamaa P, Ovaska K, Sinielnikov I, Hautaniemi S, Jänne OA. 2013. FoxA1 specifies unique androgen and glucocorticoid receptor binding events in prostate cancer cells. Cancer Res 73: 1570-1580.

Scher HI, Kelly WK. 1993. Flutamide withdrawal syndrome: Its impact on clinical trials in hormone-refractory prostate cancer. J Clin Oncol 11: 1566-1572.

Scher HI, Sawyers CL. 2005. Biology of progressive, castration-resistant prostate cancer: Directed therapies targeting the androgen-receptor signaling axis. J Clin Oncol 23: 8253-8261.

Scher HI, Fizazi K, Saad F, Taplin ME, Sternberg CN, Miller K, de Wit R, Mulders P, Chi KN, Shore ND, et al. 2012. Increased survival with enzalutamide in prostate cancer after chemotherapy. N Engl J Med 367: 1187-1197.

Schmidt LJ, Tindall DJ. 2011. Steroid $5 \alpha$-reductase inhibitors targeting BPH and prostate cancer. J Steroid Biochem Mol Biol 125: 32-38.

Schröder F, Bangma C, Angulo JC, Alcaraz A, Colombel M, McNicholas T, Tammela TL, Nandy I, Castro R. 2013. Dutasteride treatment over 2 years delays prostate-specific antigen progression in patients with biochemical failure after radical therapy for prostate cancer: Results from the randomised, placebo-controlled Avodart After Radical Therapy for Prostate Cancer. Eur Urol 63: 779-787.

Shaffer PL, Jivan A, Dollins DE, Claessens F, Gewirth DT. 2004. Structural basis of androgen receptor binding to selective androgen response elements. Proc Natl Acad Sci 101: $4758-4763$

Shah SK, Trump DL, Sartor O, Tan W, Wilding GE, Mohler JL. 2009. Phase II study of Dutasteride for recurrent pros- tate cancer during androgen deprivation therapy. J Urol 181: 621-626.

Sharifi N. 2010. New agents and strategies for the hormonal treatment of castration-resistant prostate cancer. Expert Opin Investig Drugs 19: 837-846.

Sharifi N. 2013. Mechanisms of androgen receptor activation in castration-resistant prostate cancer. Endocrinology 154: 4010-4017.

Sharifi N. 2014. Steroid receptors aplenty in prostate cancer. N Engl J Med 370: 970-971.

Sharifi N, Auchus RJ. 2012. Steroid biosynthesis and prostate cancer. Steroids 77: 719-726.

Sharifi N, Gulley JL, Dahut WL. 2005. Androgen deprivation therapy for prostate cancer. JAMA 294: 238-244.

Sharma NL, Massie CE, Ramos-Montoya A, Zecchini V, Scott HE, Lamb AD, MacArthur S, Stark R, Warren AY, Mills IG, et al. 2013. The androgen receptor induces a distinct transcriptional program in castration-resistant prostate cancer in man. Cancer Cell 23: 35-47.

Shiota M, Yokomizo A, Fujimoto N, Naito S. 2011. Androgen receptor cofactors in prostate cancer: Potential therapeutic targets of castration-resistant prostate cancer. Curr Cancer Drug Targets 11: 870-881.

Simard J, Ricketts ML, Gingras S, Soucy P, Feltus FA, Melner MH. 2005. Molecular biology of the $3 \beta$-hydroxysteroid dehydrogenase $/ \Delta^{5}-\Delta^{4}$ isomerase gene family. Endocr Rev 26: $525-582$.

Simental JA, Sar M, Lane MV, French FS, Wilson EM. 1991. Transcriptional activation and nuclear targeting signals of the human androgen receptor. J Biol Chem 266: 510518.

Smith DF, Toft DO. 2008. Minireview: The intersection of steroid receptors with molecular chaperones: Observations and questions. Mol Endocrinol 22: 2229-2240.

Stanbrough M, Bubley GJ, Ross K, Golub TR, Rubin MA, Penning TM, Febbo PG, Balk SP. 2006. Increased expression of genes converting adrenal androgens to testosterone in androgen-independent prostate cancer. Cancer Res 66: $2815-2825$.

Steers WD. 2001. 5 $\alpha$-reductase activity in the prostate. Urology 58: 17-24; discussion 24.

Sun S, Sprenger CCT, Vessella RL, Haugk K, Soriano K, Mostaghel EA, Page ST, Coleman IM, Nguyen HM, Sun $\mathrm{H}$, et al. 2010. Castration resistance in human prostate cancer is conferred by a frequently occurring androgen receptor splice variant. J Clin Invest 120: 2715-2730.

Szmulewitz RZ, Chung E, Al-Ahmadie H, Daniel S, Kocherginsky M, Razmaria A, Zagaja GP, Brendler CB, Stadler WM, Conzen SD. 2012. Serum/glucocorticoid-regulated kinase 1 expression in primary human prostate cancers. Prostate 72: 157-164.

Taplin ME, Bubley GJ, Shuster TD, Frantz ME, Spooner AE, Ogata GK, Keer HN, Balk SP. 1995. Mutation of the androgen-receptor gene in metastatic androgen-independent prostate cancer. N Engl J Med 332: 1393-1398.

Taplin ME, Bubley GJ, Ko YJ, Small EJ, Upton M, Rajeshkumar B, Balk SP. 1999. Selection for androgen receptor mutations in prostate cancers treated with androgen antagonist. Cancer Res 59: 2511-2515.

Taplin M-E, Rajeshkumar B, Halabi S, Werner CP, Woda BA, Picus J, Stadler W, Hayes DF, Kantoff PW, Vogelzang NJ, 
C. Dai et al.

et al. 2003. Androgen receptor mutations in androgenindependent prostate cancer: Cancer and Leukemia Group B Study 9663. J Clin Oncol 21: 2673-2678.

Taplin M-E, Montgomery B, Logothetis CJ, Bubley GJ, Richie JP, Dalkin BL, Sanda MG, Davis JW, Loda M, True LD, et al. 2014. Intense androgen-deprivation therapy with abiraterone acetate plus leuprolide acetate in patients with localized high-risk prostate cancer: Results of a randomized phase II neoadjuvant study. J Clin Oncol 32: 3705-3715.

Thadani-Mulero M, Nanus DM, Giannakakou P. 2012. Androgen receptor on the move: Boarding the microtubule expressway to the nucleus. Cancer Res 72: 4611-4615.

The Cancer Genome Atlas Research Network. 2015. The molecular taxonomy of primary prostate cancer. Cell 163: $1011-1025$.

Thigpen AE, Cala KM, Russell DW. 1993. Characterization of Chinese hamster ovary cell lines expressing human steroid $5 \alpha$-reductase isozymes. J Biol Chem 268: 17404-17412.

Thirumalai A, Cooper LA, Rubinow KB, Amory JK, Lin DW, Wright JL, Marck BT, Matsumoto AM, Page ST. 2016. Stable intraprostatic dihydrotestosterone in healthy medically castrate men treated with exogenous testosterone. J Clin Endocrinol Metab 101: 2937-2944.

Thomas LN, Douglas RC, Lazier CB, Too CKL, Rittmaster RS, Tindall DJ. 2008. Type 1 and type $25 \alpha$-reductase expression in the development and progression of prostate cancer. Eur Urol 53: 244-252.

Tilley WD, Marcelli M, Wilson JD, McPhaul MJ. 1989. Characterization and expression of a cDNA encoding the human androgen receptor. Proc Natl Acad Sci 86: 327-331.

Titus MA, Schell MJ, Lih FB, Tomer KB, Mohler JL. 2005. Testosterone and dihydrotestosterone tissue levels in recurrent prostate cancer. Clin Cancer Res 11: 4653-4657.

Tomlins SA, Rhodes DR, Perner S, Dhanasekaran SM, Mehra R, Sun X-W, Varambally S, Cao X, Tchinda J, Kuefer R, et al. 2005. Recurrent fusion of TMPRSS2 and ETS transcription factor genes in prostate cancer. Science 310: 644-648.

Tomlins SA, Bjartell A, Chinnaiyan AM, Jenster G, Nam RK, Rubin MA, Schalken JA. 2009. ETS gene fusions in prostate cancer: From discovery to daily clinical practice. Eur Urol 56: 275-286.

Tran C, Ouk S, Clegg NJ, Chen Y, Watson PA, Arora V, Wongvipat J, Smith-Jones PM, Yoo D, Kwon A, et al. 2009. Development of a second-generation antiandrogen for treatment of advanced prostate cancer. Science 324: 787-790.

Umesono K, Evans RM. 1989. Determinants of target gene specificity for steroid/thyroid hormone receptors. Cell 57: 1139-1146.

Veldscholte J, Berrevoets CA, Ris-Stalpers C, Kuiper GG, Jenster G, Trapman J, Brinkmann AO, Mulder E. 1992. The androgen receptor in LNCaP cells contains a mutation in the ligand binding domain which affects steroid binding characteristics and response to antiandrogens. J Steroid Biochem Mol Biol 41: 665-669.

Wallén MJ, Linja M, Kaartinen K, Schleutker J, Visakorpi T. 1999. Androgen receptor gene mutations in hormonerefractory prostate cancer. J Pathol 189: 559-563.

Wang Q, Li W, Zhang Y, Yuan X, Xu K, Yu J, Chen Z, Beroukhim R, Wang H, Lupien M, et al. 2009. Androgen receptor regulates a distinct transcription program in androgen-independent prostate cancer. Cell 138: 245-256.

Wang D, Garcia-Bassets I, Benner C, Li W, Su X, Zhou Y, Qiu J, Liu W, Kaikkonen MU, Ohgi KA, et al. 2011a. Reprogramming transcription by distinct classes of enhancers functionally defined by eRNA. Nature 474: 390-394.

Wang Y, Lonard DM, Yu Y, Chow DC, Palzkill TG, O’Malley BW. 2011b. Small molecule inhibition of the steroid receptor coactivators, SRC-3 and SRC-1. Mol Endocrinol 25: $2041-53$.

Wang Y, Lonard DM, Yu Y, Chow DC, Palzkill TG, Wang J, Qi R, Matzuk AJ, Song X, Madoux F, et al. 2014. Bufalin is a potent small-molecule inhibitor of the steroid receptor coactivators SRC-3 and SRC-1. Cancer Res 74: 1506-1517.

Ware KE, Garcia-Blanco MA, Armstrong AJ, Dehm SM. 2014. Biologic and clinical significance of androgen receptor variants in castration resistant prostate cancer. Endocr Relat Cancer 21: T87-T103.

Watson PA, Chen YF, Balbas MD, Wongvipat J, Socci ND, Viale A, Kim K, Sawyers CL. 2010. Constitutively active androgen receptor splice variants expressed in castrationresistant prostate cancer require full-length androgen receptor. Proc Natl Acad Sci 107: 16759-16765.

Wilson JD. 2001. The role of $5 \alpha$-reduction in steroid hormone physiology. Reprod Fertil Dev 13: 673-678.

Wilson EM, French FS. 1976. Binding properties of androgen receptors. Evidence for identical receptors in rat testis, epididymis, and prostate. J Biol Chem 251: 56205629.

Xu Y, Dalrymple SL, Becker RE, Denmeade SR, Isaacs JT. 2006. Pharmacologic basis for the enhanced efficacy of dutasteride against prostatic cancers. Clin Cancer Res 12: 4072-4079.

Xu D, Zhan Y, Qi Y, Cao B, Bai S, Xu W, Gambhir SS, Lee P, Sartor O, Flemington EK, et al. 2015. Androgen receptor splice variants dimerize to transactivate target genes. Cancer Res 75: 3663-3671.

Zhang A, Zhang J, Plymate S, Mostaghel EA. 2016. Classical and non-classical roles for pre-receptor control of DHT metabolism in prostate cancer progression. Horm Cancer 7: $104-113$.

Zhao Y, Tindall DJ, Huang H. 2014. Modulation of androgen receptor by FOXA1 and FOXO1 factors in prostate cancer. Int J Biol Sci 10: 614-619.

Zhou ZX, Lane MV, Kemppainen JA, French FS, Wilson EM. 1995. Specificity of ligand-dependent androgen receptor stabilization: Receptor domain interactions influence ligand dissociation and receptor stability. Mol Endocrinol 9: 208-218.

Zhou HJ, Yan J, Luo W, Ayala G, Lin SH, Erdem H, Ittmann M, Tsai SY, Tsai MJ. 2005. SRC-3 is required for prostate cancer cell proliferation and survival. Cancer Res 65: 7976-7983.

Zhu YS, Imperato-McGinley JL. 2009. 5 $\alpha$-reductase isozymes and androgen actions in the prostate. Ann NY Acad Sci 1155: 43-56

Ziada A, Barqawi A, Glode LM, Varella-Garcia M, Crighton F, Majeski S, Rosenblum M, Kane M, Chen L, Crawford ED. 2004. The use of trastuzumab in the treatment of hormone refractory prostate cancer; phase II trial. Prostate 60: $332-337$. 


\section{$\&_{\mathrm{CSH}}^{\infty} \&$ Cold Spring Harbor

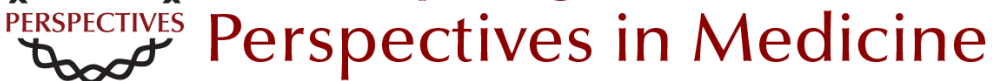

\section{Androgen Signaling in Prostate Cancer}

Charles Dai, Hannelore Heemers and Nima Sharifi

Cold Spring Harb Perspect Med 2017; doi: 10.1101/cshperspect.a030452 originally published online April 7, 2017

\section{Subject Collection Prostate Cancer}

Anatomic and Molecular Imaging in Prostate Cancer

Eric T. Miller, Amirali Salmasi and Robert E. Reiter

The Epidemiology of Prostate Cancer

Claire H. Pernar, Ericka M. Ebot, Kathryn M. Wilson, et al.

Prostate Stem Cells and Cancer Stem Cells Jia J. Li and Michael M. Shen

Prostate Cancer Epigenetics: From Basic Mechanisms to Clinical Implications Srinivasan Yegnasubramanian, Angelo M. De Marzo and William G. Nelson

\section{The Genomics of Prostate Cancer: A Historic} Perspective Mark A. Rubin and Francesca Demichelis

Neuroendocrine Differentiation in Prostate

Cancer: Emerging Biology, Models, and Therapies Loredana Puca, Panagiotis J. Vlachostergios and Himisha Beltran

DNA Damage Response in Prostate Cancer Matthew J. Schiewer and Karen E. Knudsen

Transcriptional Regulation in Prostate Cancer David P. Labbé and Myles Brown
New Opportunities for Targeting the Androgen Receptor in Prostate Cancer Margaret M. Centenera, Luke A. Selth, Esmaeil Ebrahimie, et al.

Prostate Cancer Research at the Crossroads Michael M. Shen and Mark A. Rubin

Immunotherapy for Prostate Cancer Nicholas J. Venturini and Charles G. Drake

Molecular Pathology of High-Grade Prostatic Intraepithelial Neoplasia: Challenges and Opportunities Levent Trabzonlu, Ibrahim Kulac, Qizhi Zheng, et al.

Metastases in Prostate Cancer Federico La Manna, Sofia Karkampouna, Eugenio Zoni, et al.

Genetically Engineered Mouse Models of Prostate Cancer in the Postgenomic Era Juan M. Arriaga and Cory Abate-Shen

Molecular Biomarkers in the Clinical Management of Prostate Cancer Aaron M. Udager and Scott A. Tomlins

Metabolic Vulnerabilities of Prostate Cancer: Diagnostic and Therapeutic Opportunities Giorgia Zadra and Massimo Loda

For additional articles in this collection, see http://perspectivesinmedicine.cshlp.org/cgi/collection/ 